\title{
Effect of composition and sintering temperature on thermal properties of zeolite-alumina composite materials
}

\author{
JAMAL-ELDIN F. M. IBRAHIM - Institute of Ceramics and Polymer Engineering, \\ University of Miskolc, Hungary $=$ jamalfadoul@gmail.com \\ DMITRY A. SHUSHKOV - Institute of Geology, FRC Komi Science Center, \\ Ural Branch of the Russian Academy of Sciences, Russian Federation - dashushkov@geo.komisc.ru \\ EMESE KUROVICS - Institute of Ceramics and Polymer Engineering, \\ University of Miskolc, Hungary - fememese@uni-miskolc.hu \\ Монамmed TIHTIH - Institute of Ceramics and Polymer Engineering, \\ University of Miskolc, Hungary - medtihtih@gmail.com \\ OLGA B. KOTOVA - Institute of Geology, FRC Komi Science Center, \\ Ural Branch of the Russian Academy of Sciences, Russian Federation • kotova@geo.komisc.ru \\ PÉter PALA - Refratechnik Hungaria Ltd, Hungary \\ LÁszLó A. GÖMZE - Institute of Ceramics and Polymer Engineering, \\ University of Miskolc, Hungary, IGREX Engineering Service Ltd • femgomze@uni-miskolc.hu \\ Érkezett: 2020. 06. 30. - Received: 30. 06. 2020. - https://doi.org/10.14382/epitoanyag-jsbcm.2020.21
}

\begin{abstract}
This research work provides a technical description of the utilization of natural zeolites in the synthesis of ceramic composite material using mechanical milling and reactive sintering technique. Two commercially available minerals (Natural zeolite from Mád in Tokaj region and MOTIM $\mathrm{Al}_{2} \mathrm{O}_{3}$ ) were used as starting raw materials, A comprehensive analysis has been conducted for the detailed characterization of raw materials as well as produced products, the analysis combines the mineralogical examination using X-ray diffraction (XRD) together with chemical constituent determination by (XRF) and thermoanalytical studies using (TG/DTA), heating electron microscope and thermal conductivity analyzer to determine the influence of sintering temperatures on the thermal properties of the produced zeolite-alumina composite materials. Based on the results obtained from XRD, XRF and TG/DTA, the authors have found a great connection between the composition, firing temperature and thermal properties of the produced ceramic samples. Keywords: zeolite-alumina, composite materials, uniaxial compaction, thermal properties Kulcsszavak: zeolit - alumínium-oxid,kompozit anyag, egytengelyú sajtolás, termikus tulajdonságok
\end{abstract}

\section{Introduction}

Currently, ceramics materials both traditional and advance materials have attracted huge interest in research and industries [1-14]. Zeolites are a large group of naturally occurring minerals, normally consist of hydrated aluminosilicates of sodium, potassium, calcium, and barium which are formed from largely extending three-dimensional frameworks of $\left[\mathrm{SiO}_{4}\right]^{4-}$ and $\left[\mathrm{AlO}_{4}\right]^{5-}$ tetrahedra bonded from their corners with shared oxygen atoms (Fig. 1) [15] . Zeolite is characterized by their porous structures with large interconnected cavities that accommodate cations such as $\mathrm{Na}^{+}, \mathrm{K}^{+}, \mathrm{Ca}^{2+}$ and $\mathrm{Mg}^{2+}$ that neutralized the negatively charged framework [16,17]. Various structures (more than 200) are introduced for zeolites, in which $20 \%$ is considered as natural minerals and the reminders are synthetic materials. Zeolite which can be prepared in a high amount at relatively moderate temperatures is popular for large-scale applications. Therefore, high-alumina zeolites with large pore systems, for example, zeolites Linde type A (LTA) and zeolites Linde type $\mathrm{X}$, are the most highly used zeolites in industries [15].

Large effort has lately been devoted to produce ceramic composite materials with enhanced properties using available and cost-effective materials. Natural zeolites are interesting
Jamal-Eldin F. M. IBRAHIM is a lecturer in the University of Bahri, Khartoum, Sudan, he graduated from University of Marmara Istanbul, Turkey, Institute of Pure and Applied

Sciences, Department of Metallurgical and Materials Engineering, for the time being, he is a PhD student in the University of Miskolc, Institute of Polymer and Ceramics Engineering, under supervision of Prof. L. A. Gömze

Dmitry A. SHUSHKOV is Researcher of Laboratory of Technology of Mineral Raw, Institute of Geology Komi SC UBRussian Academy of Sciences. Author and coauthor of 2 patents and more than 40 scientific articles. Russian Mineralogical Society

Emese KUROVICS

is graduated from the University of Miskolc Department of Ceramics and Silicate Engineering as a material engineer, where she continues her study as PhD student under supervision of Prof. L. A. Gömze.

Mohammed TIHTIH Is a lecturer in the Sidi Mohamed Ben abdellah University, Morocco, he graduated from Faculty of sciences Dhar El Mahraz, Fez, Morocco, Department of Physics, for the time being, he is a PhD student in the University of Miskolc, Institute of Ceramics and Polymer Engineering, under supervision of Prof. L. A. Gömze

Olga B. KOTOVA is Head of Laboratory of Technology of Mineral Raw, Institute of Geology Komi SC UB Russian Academy of Sciences. Author and co-author of 10 books, 4 patents and more than 200 scientific articles. President of ICAM-2019. The member of Science Council of Russian Mineralogical Society.

Péter PALA

Is a chemical engineer who finished his study at the University of Pannonia. He has been working in the ceramics industry since 2003, at present he is the managing director of Refratechnik Hungaria Ltd.

László A. GÖMZE is establisher and professor of the Department of Ceramics and Silicate Engineering in the University of Miskolc, Hungary. He is author or co-author of 2 patents, 6 books and more than 300 scientific papers.

candidates that can be used in the synthesis of many ceramic composites [18-23] due to their fascinating properties such as large surface area, high ions exchange capacity, high sorption capacity and their porous structure that can host secondary materials. Many applications for zeolite and zeolite-based materials have been introduced including building materials such as bricks, lightweight aggregate and additives for cement and concretes etc. Other technical applications of zeolitebased materials in many industries have also been reported for instance heterogeneous catalysis, sorbents and ion exchangers [24-25].

The ceramic forming techniques involve many processes such as pressing, extrusion, injection moulding, casting, solgel ect. The pressing technique is advantageous over other methods due to its low cost, simplicity and high productivity. All these production lines involve several steps, including, raw materials preparation, shaping techniques, drying method, 
sintering temperature and residence time. During the firing process which normally take places at a temperature ranging from $1 / 2$ to $3 / 4$ of the melting temperature of the ceramic raw materials [26]. The ceramic green bodies undergo a series of important changes, involving binder burnout, physicochemical reactions (e.g. decomposition, oxidation), allotropic transformation, and sintering. These changes play a crucial role in the quality of the produced samples [27]. Due to the physicochemical reactions the sample raw materials are transformed into new complex compounds which govern the stability of the final ceramic products because of the change in volume of the system (increase or decrease). The densification due to the sintering has high influence in the physical and thermal properties of the ceramic products like porosity, density, and thermal conductivity, etc.
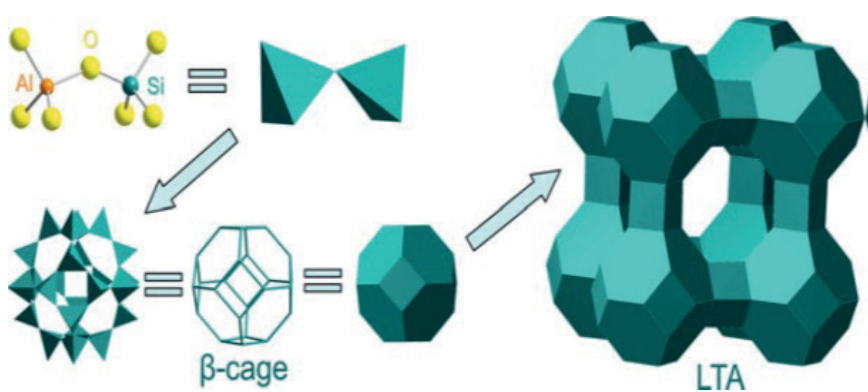

\footnotetext{
1. ábra A zeolitok sematikus felépitése SiO4 és AlO4 tetraéderekböl és a zeolit egyszerüsitett poliéderes szerkezetének ábrázolása [15]

Fig. 1 Schematic construction of zeolites from $\mathrm{SiO}_{4}$ and $\mathrm{AlO}_{4}$ tetrahedra and simplified polyhedra representation of a zeolite structure [15]
}

The goal of this paper is to investigate the effect of the change of sintering temperatures on thermal properties of zeolitealumina composite materials. The natural zeolite is taken from Mád in Tokaj region which is a well-known area for a large deposit of natural zeolite, located on the north of Hungary as shown in Fig. 2.

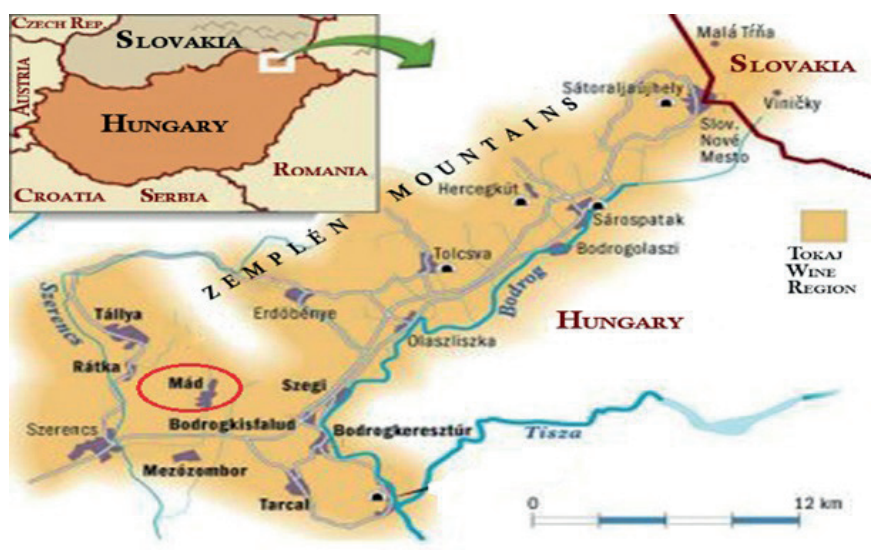

2. ábra A természetes zeolit elhelyezkedése Mádban (Tokaji régió, Magyarország) Fig. 2 Location of the natural zeolite in Mád (Tokaj region, Hungary)

\section{Materials and experiments}

\subsection{Preparation methods}

Natural zeolite from Mád (Tokaj region) and MOTIM $\mathrm{Al}_{2} \mathrm{O}_{3}$ powders were taken as starting raw materials. Five different compositions of zeolite and $\mathrm{Al}_{2} \mathrm{O}_{3}$ weight ratios were mixed in Retsch PM 400 planetary ball mill operated at the speed of $150 \mathrm{rpm}$ for 15 minutes. The prepared powder mixtures are then compacted using a uniaxial compacting machine with a mechanical pressure of $100 \mathrm{MPa}$ to produce cylindrical ceramic discs with a thickness of approximately $10 \mathrm{~mm}$ and a diameter of $25 \mathrm{~mm}$. The produced ceramic compacts were fired at $1100^{\circ} \mathrm{C}, 1150^{\circ} \mathrm{C}, 1200^{\circ} \mathrm{C}, 1250^{\circ} \mathrm{C}$ and $1300^{\circ} \mathrm{C}$ temperatures, using a programmable laboratory furnace with the heating rate of $60^{\circ} \mathrm{C} / \mathrm{h}$ and residence time of $3 \mathrm{~h}$ at the highest temperature. The samples of the sintered specimens are shown in Fig. 3.

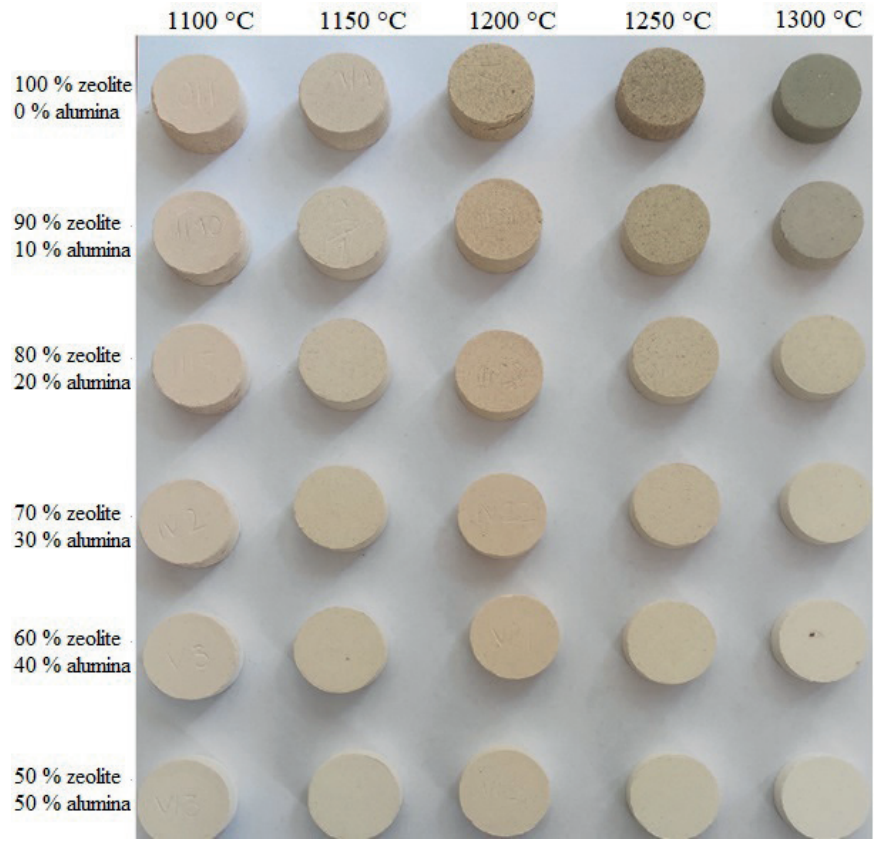

3. ábra Különbözö összetételü minták, különbözö hömérsékleten szinterelve

Fig. 3 Samples with different composition sintered at different temperature

\subsection{Characterization techniques}

Phase identification of raw materials and the final product was done via XRD method using a Rigaku Miniflex II X-ray diffractometer, with $\mathrm{CuKa}$ radiation $(\lambda=1.54184 \mathrm{~A})$. XRD patterns were scanned in step size of $0.01016^{\circ}$ in a range of $2 \theta$ intervals of $0-70^{\circ}$. The effect of sintering temperature on the raw materials and prepared mixtures was also carried out using the heating microscope as well as the concurrent thermogravimetric analysis (TGA) and differential thermal analysis (DTA) methods which enable the persistent determination of the samples weight loss based on the temperature. The thermal conductivity of the prepared ceramics is performed via C-Therm TCi Thermal Conductivity Analyzer which applies the modified transient plane source (MTPS) technique in the determination of the thermal conductivity and effusivity of materials.

\section{Results and discussions}

\subsection{XRD investigations}

The XRD analysis of the raw materials (natural zeolite powder) from Mád (Tokaj region, Hungary) are confirmed to have many minerals phases together with zeolite (clinoptilolite) as shown in Fig. 4. Table 1 shows the oxides and phases 
percentages of the natural zeolite in wt.\% acquired from XRF and XRD tests. Silica (cristobalite) is found in the highest amount with a percentage of $50 \%$ while montmorillonite accounts for $30 \%$ and the other minerals represent $20 \%$ of the total amount.

Based on the composition of the oxides the overall amount of silica is found to be $82.92 \mathrm{wt}$.\% and the reminders are other oxides like alumina, magnesia and sodium oxide.

Fig. 5 shows the XRD diffractogram of alumina from MOTIM. The XRD investigation reveals a complete match of the peaks which is an indication for the existence of alumina with single-phase (corundum).

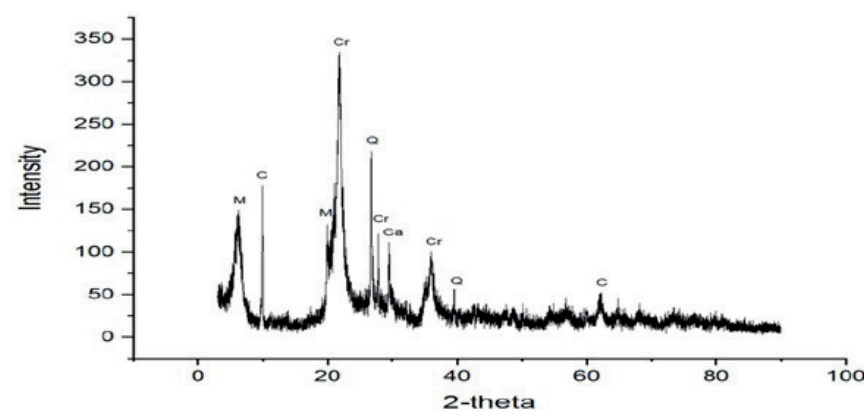

4. ábra A természetes zeolit minták XRD diffraktogramja (M: montmorillonit; C: klinoptilolit; Cr: cristobalite; Q: kvarc; Ca: kalcit)

Fig. 4 XRD diffractogram of the natural zeolite specimens (M: montmorillonite; C: clinoptilolite; Cr: cristobalite; Q: quartz; Ca: calcite)

\begin{tabular}{|c|c|c|c|c|c|c|c|c|c|}
\hline & wt. $\%$ & $\mathrm{CaO}$ & $\mathrm{SiO}_{2}$ & $\mathrm{Al}_{2} \mathrm{O}_{3}$ & MgO & $\mathrm{Na}_{2} \mathrm{O}$ & $\mathrm{CO}_{2}$ & $\mathrm{H}_{2} \mathrm{O}$ & $\begin{array}{l}\text { Loss on } \\
\text { ignition }\end{array}$ \\
\hline Quartz & 8.00 & & 8.00 & & & & & & 0.00 \\
\hline Cristobalite & 50.00 & & 50.00 & & & & & & 0.00 \\
\hline $\begin{array}{l}\text { Montmoril- } \\
\text { lonite }\end{array}$ & 30.00 & & 19.13 & 4.06 & 3.21 & 0.74 & & 2.87 & 2.87 \\
\hline Calcite & 2.00 & 1.12 & & & & & 0.88 & & 0.88 \\
\hline Clinoptilolite & 10.00 & & 5.79 & 1.89 & & 0.57 & & 1.60 & 1.75 \\
\hline Total & 100.00 & 1.12 & 82.92 & 5.95 & 3.21 & 1.31 & 0.88 & 4.47 & 5.50 \\
\hline
\end{tabular}

1. táblázat Az oxidok és az ásványi fázisok összetétele és tömegszázaléka

Table 1 The composition and weight percentage of the oxides and mineral phases

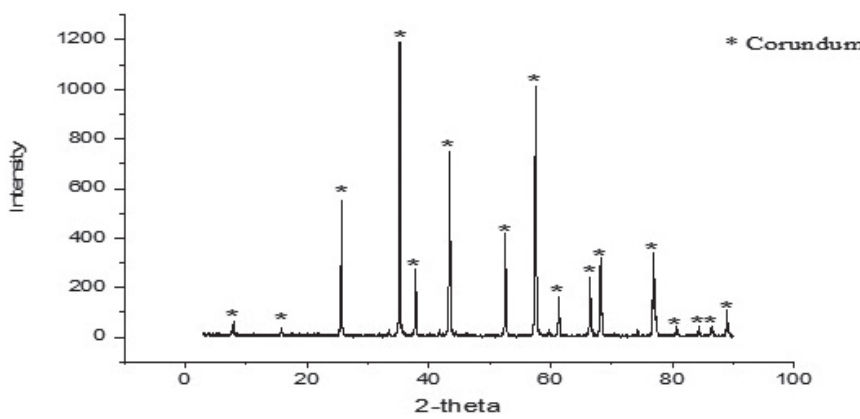

5. ábra Az alumínium-oxid XRD diffraktogramja

Fig. 5 XRD diffractogram of alumina

\subsection{Thermal properties of raw materials}

The thermal characteristics of naturally occurring zeolites vary remarkably from one type to another and highly govern their applications. Upon heating, zeolites in general tends to lose water (free and crystalline) and experience dehydrationaccompanied volume shrinkage, which is completely or partially irreversible, especially when zeolites undergo modification in the tetrahedral structure.

TG/DTA curves of the ceramic raw materials with $90 \%$ zeolite and 10\% alumina are shown in Fig. 6. Overall weight loss of approximately $8.4 \%$ was obtained at $1190^{\circ} \mathrm{C}$. Firstly, $2.01 \%$ decrease in the mass was observed in a temperature range of $40-102{ }^{\circ} \mathrm{C}$ which accounts to the removal of free water which normally exist in the zeolites surface, micropores and channels [26] Secondly, a weight loss of $3.74 \%$ was obtained in a temperature between $102^{\circ} \mathrm{C}$ and $163,8^{\circ} \mathrm{C}$ which could be attributed to the evaporation of the water in the closed pores and burning of the organic content. In the third steps and at the temperature between $163,8^{\circ} \mathrm{C}-242.2^{\circ} \mathrm{C}$ a weight loss of $4.57 \%$ was gained which could be due to the continuous burning of the low flammable materials (hydrocarbons). The largest weight loss was revealed at a temperature between $242{ }^{\circ} \mathrm{C}$ and $761^{\circ} \mathrm{C}$ which ascribed to the evaporation of crystalline water. Small reaction was obtained at about $761-1190^{\circ} \mathrm{C}$ which could be assigned to the decomposition of calcite and montmorillonite and/or formation of mullite and anorthite.

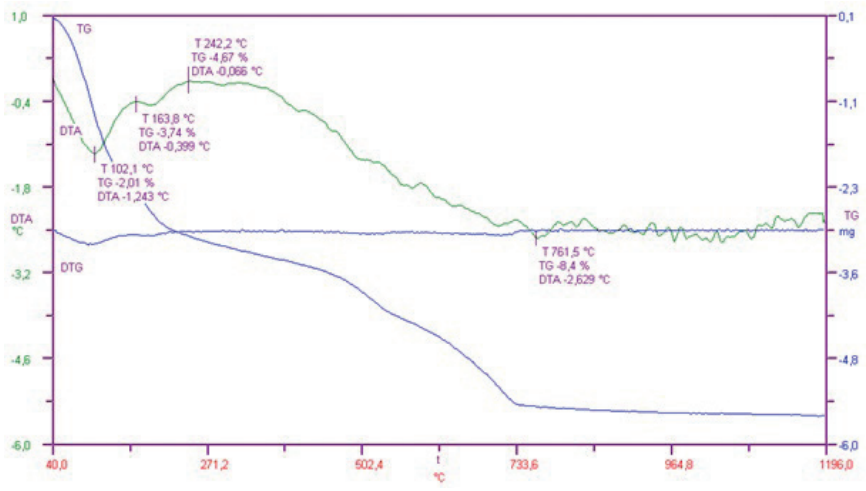

6. ábra $90 \%$ zeolit-10\% alumínium-oxid por DTA, TG és DTG görbéi Fig. 6 DTA, TG and DTG curves of $90 \%$ zeolite-10\% alumina powder

The behavior of the ceramic mixtures under firing is examined using a Camar Elettronica heating microscope as shown in Fig. 7. Zeolite-alumina mixtures were stable up to $1358^{\circ} \mathrm{C}$, no melting was observed only sintering of the mixtures was noticed with $5 \%$ height shrinkage.

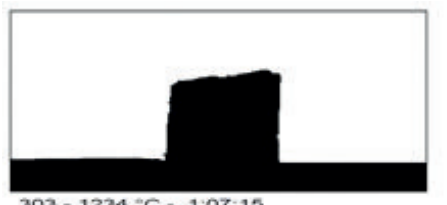
$303-1234^{\circ} \mathrm{C}-1: 07: 15$
Height $956^{\circ}$ Angle $93^{\circ}$

$90 \%$ zeolite-10\% alumina

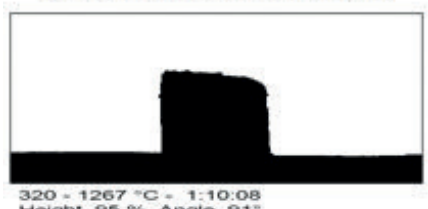

$320-12677^{\circ C}$ - $1: 10: 08$
Height $95 \%$ Angie $91^{\circ}$

$70 \%$ zeolite- $30 \%$ alumina

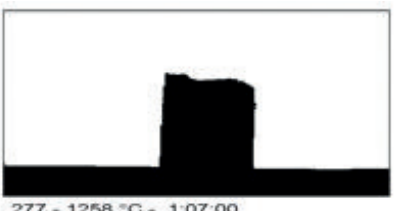
$277-1258$ "C - 1:07:00
Height $95 \%$ Angie 90" $80 \%$ zeolite- $20 \%$ alumina

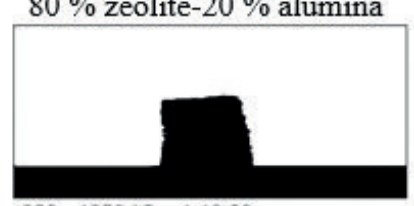

$320-1358$ "C $-1: 19: 28$
Height $95 \%$ Angle 94 "

$60 \%$ zeolite- $40 \%$ alumina

7. ábra A zeolit-alumínium-oxid keverékek különböző összetételủ hevitőmikroszkópos képei

Fig. 7 Heating microscope images of different composition of zeolite-alumina mixtures 
Natural zeolite from Mád (Tokaj region, Hungary) contains different minerals, therefore when mixed with alumina and fired, it undergoes various complex processes including dehydration of water followed by allotropic transformation (quartz to cristobalite), physicochemical reactions (formation of new mineral phase) and sintering and it can be clearly seen in Fig. 3 which shows the change in colour and the volume shrinkage of the produced specimens based on the change in firing temperature. This could be a clue for the abovementioned processes.

XRD of the sintered samples Fig. 8 confirms the decomposition of montmorillonite and calcite, as well as the formation of mullite and anorthite at a temperature above $1000{ }^{\circ} \mathrm{C}$, moreover, the amount of amorphous phase is increasing at higher sintering temperature. It is worth mentioning that in both cases, the firing of (natural zeolite and natural zeolite + alumina) leads to formation of mullite and anorthite but in case of firing zeolite-alumina mixture, larger amount of mullite and anorthite is expected to produce. Moreover, the volume shrinkage is increasing with increasing the firing temperature and hence the density is also increased.

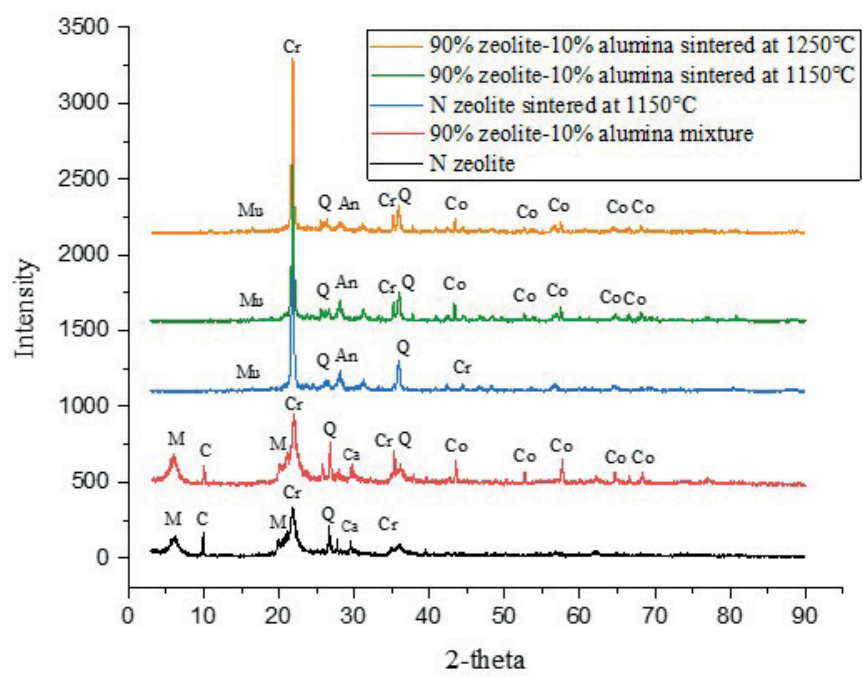

8. ábra A különbözö hömérsékleten szinterezett minták XRD diffraktogramja (M: montmorillonit, C: klinoptilolit, Cr: kristobalit Q: kvarc, Ca: kalcit, Mu: mullit, An: anortit, Co: korund)

Fig. 8 The XRD pattern of samples sintered at different temperatures (M: montmorillonite, C: clinoptilolite, Cr: cristobalite Q: quartz, Ca: calcite, Mu: mullite, An: anorthite, Co: corundum).

\subsection{Thermal conductivity}

The thermal conductivity of the prepared samples as a function of zeolite composition sintered at different temperatures $\left(1100^{\circ} \mathrm{C}, 1150^{\circ} \mathrm{C}, 1200^{\circ} \mathrm{C}, 1250^{\circ} \mathrm{C}\right.$ and $1300^{\circ} \mathrm{C}$ ) are shown in Fig. 9. Thermal conductivity of the samples tends to increase with increasing the sintering temperature due to the increase in density and reduction in porosity, the lowest thermal conductivity is found to be $0.3 \mathrm{~W} / \mathrm{mK}$ achieved when $100 \%$ natural zeolite is sintered at $1100^{\circ} \mathrm{C}$. It can be noticed that increasing the alumina composition in the produced specimens tends to increase the thermal conductivity and this could be attributed to the formation of mullite and anorthite.

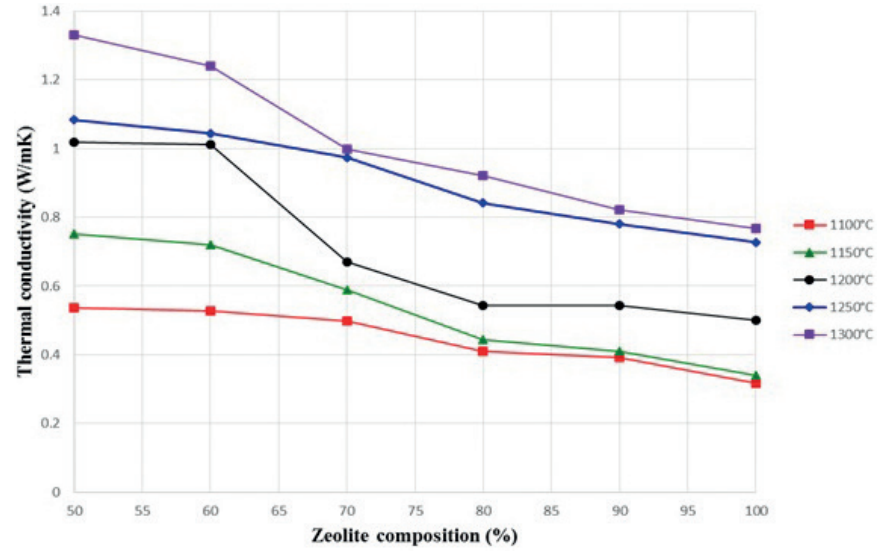

9. ábra A különbözö hömérsékleten szinterezett zeolit-alumínium-oxid minták hövezetöképessége

Fig. 9 The thermal conductivity of the zeolite-alumina samples sintered at different temperatures

\section{Conclusions}

Thermally-induced volume shrinkage and structural transformation were obtained due to the loss of free and combined water molecules by dehydration, decomposition of montmorillonite and calcite and formation of a new phases (mullite and anorthite) which firstly noticed by the change in the colour of the produced specimens and further confirmed by XRD, the formation of mullite and anorthite has resulted from the reaction of the added amount of alumina together with silica and the decomposed montmorillonite existing in the natural zeolite. All these processes lead to increase in the volume shrinkage of the prepared samples and hence increase the density and as a result, the thermal conductivity of the samples is also increased. The composition of the mixtures of the raw materials is found to has a large influence in the thermal conductivity and this could be resulted from the addition of alumina that induced the formation of mullite and anorthite at higher temperature.

\section{Acknowledgments}

The described article was carried out as part of the EFOP3.6.1-16-00011 "Younger and Renewing University Innovative Knowledge City - institutional development of the University of Miskolc aiming at intelligent specialisation" project implemented in the framework of the Szechenyi 2020 program. The realization of this project is supported by the European Union, co-financed by the European Social Fund. We would like to express our massive thank to Mr. Tibor MÁTYÁS from Geoproduct-Kružlov for his help and cooperation

\section{References}

[1] Gömze, László A., et al. "Conventional Brick Clays as a Challenge of Materials Science-New Explanation of Drying Sensitivities." IOP Conference Series: Materials Science and Engineering. Vol. 613. No. 1. IOP Publishing, 2019. https://doi.org/10.1088/1757-899X/613/1/012005

[2] Kurovics, Emese, et al. "Preparation of particle-reinforced mullite composite ceramic materials using kaolin and IG-017 bio-origin additives." Építőanyag - JSBCM 71.4, 2019.

https://doi.org/10.14382/epitoanyag-jsbcm.2019.20 
[3] Gömze, László A., Emese Kurovics, and Ludmila N. Gömze. "Changing the rheo-mechanical models of light metal $\mathrm{Ti}$ and Ti-alloy powders under uniaxial compaction." Journal of Physics: Conference Series. Vol. 1045. No. 1. IOP Publishing, 2018.

https://doi.org/10.1088/1742-6596/1045/1/012001

[4] Grigoriev, Mihail V., et al. "Deformation and fracture of alumina ceramics with hierarchical porosity.” Építőanyag - JSBCM 70.1, 2018.

https://doi.org/10.14382/epitoanyag-jsbcm.2018.1

[5] Buyakov, A. S., et al. "Formation of pore structure in zirconia-alumina ceramics." SCIENCE III. 109, 2018

[6] Gömze, László A., et al. "Development ceramic floor tiles with increased shear and pressure strengths." Építőanyag - JSBCM, 70.12018. https://doi.org/10.14382/epitoanyag-jsbcm.2018.3

[7] Gömze, L. A., and L. N. Gömze. "Rheological principles of development hetero-modulus and hetero-viscous complex materials with extreme dynamic strength." IOP Conference Series: Materials Science and Engineering. Vol. 175. No. 1. IOP Publishing, 2017. https://doi.org/10.1088/1757-899X/175/1/012001

[8] Gömze, A. L., and L. N. Gömze. "Rheo-mechanical model for self-healing asphalt pavement." Journal of Physics: Conference Series. Vol. 790. No. 1. IOP Publishing, 2017. https://doi.org/10.1088/1742-6596/790/1/012001

[9] Kocserha, I., et al. "Characterisation of the wall-slip during extrusion of heavy-clay products." Journal of Physics: Conference Series. Vol. 790. No. 1. IOP Publishing, 2017. https://doi.org/10.1088/1742-6596/790/1/012013

[10] Dedova, E. S., et al. "Structure and thermal behavior of zirconium tungstate under heating." IOP Conference Series: Materials Science and Engineering. Vol. 140. No. 1. IOP Publishing, 2016 https://doi.org/10.1088/1757-899X/140/1/012007

[11] Kurovics, E., A. Y. Buzimov, and L. A. Gömze. "Influence of raw materials composition on firing shrinkage, porosity, heat conductivity and microstructure of ceramic tiles." IOP Conference Series: Materials Science and Engineering. Vol. 123. No. 1. IOP Publishing, 2016. https://doi.org/10.1088/1757-899X/123/1/012058

[12] Kotova, O. B., A. V. Ponaryadov, and L. A. Gömze. "Hydrothermal synthesis of $\mathrm{TiO} 2$ nanotubes from concentrate of titanium ore of Pizhemskoe deposit (Russia)." Vestnik IG Komi SC UB RUS"1(253), (2016): 34-36. https://doi.org/10.19110/2221-1381-2016-1-34-36

[13] Gömze, L. A., et al. "Methods and equipment for the investigation of rheological properties of complex materials like convectional brick clays and ceramic reinforced composites." Építonanyag -JSBCM (Online) 4 (2015): 143. http://dx.doi.org/10.14382/epitoanyag-jsbcm.2015.24

[14] Tihtih, M., et al. "Study on the effect of Bi dopant on the structural and optical properties of $\mathrm{BaTiO} 3$ nanoceramics synthesized via sol-gel method." Journal of Physics: Conference Series. Vol. 1527. No. 1. IOP Publishing, 2020. https://doi.org/10.1088/1742-6596/1527/1/012043

[15] Inamuddin and M. Luqman, Ion exchange technology I: Theory and materials, Springer, New York, 2012.

[16] A. Dyer, An introduction to zeolite molecular sieves, John Wiley and Sons, Chichester, 1988
[17] H. van Bekkum, E.M. Flanigen and J.C. Jansen, Introduction to zeolite science and practice, Studies in Surface Science and Catalysis 137, Elsevier Science B.V, Amestrdam, 2001.

[18] Kotova, Olga B., et al. "Composite materials based on zeolitemontmorillonite rocks and aluminosilicate wastes." Építőanyag JSBCM 71.4, 2019. https://doi.org/10.14382/epitoanyag-jsbcm.2019.22

[19] Buzimov, A. Y., et al. "Effect of Mechanical Treatment on the Structure and Properties of Natural Zeolite." Inorganic Materials: Applied Research 9.5, 910-915. 2018. https://doi.org/10.1088/1742-6596/790/1/012004

[20] Buzimov, Alexandr Y., et al. "effect of mechanical treatment on properties of Si-Al-o zeolites.” Építőanyag (Online) 1: 23-26, (2018). https://doi.org/10.14382/epitoanyag-jsbcm.2018.1

[21] Buzimov, A. Y., et al. "Effect of mechanical treatment on properties of zeolites with chabazite structure." Journal of Physics: Conference Series. Vol. 790. No. 1. IOP Publishing, 2017. https://doi.org/10.1088/1742-6596/790/1/012004

[22] Corma, A., et al. "Interaction of zeolite alumina with matrix silica in catalytic cracking catalysts.” Applied catalysis 66.1. 45-57, 1990. https://doi.org/10.1016/S0166-9834(00)81626-7

[23] Wongcharee, Surachai, Vasantha Aravinthan, and Laszlo Erdei "Mesoporous activated carbon-zeolite composite prepared from waste macadamia nut shell and synthetic faujasite." Chinese journal of chemical engineering 27.1, 226-236, 2019 https://doi.org/10.1016/j.cjche.2018.06.024

[24] Stocker, Kristina, et al. "Characterization and utilization of natura zeolites in technical applications." BHM Berg-und Hüttenmännische Monatshefte 162.4, 142-147, 2017 https://doi.org/10.1007/s00501-017-0596-5

[25] Petranovskii, V., et al. "Potential uses of natural zeolites for the development of new materials: short review." MATEC Web of Conferences. Vol. 85. EDP Sciences, 2016. https://doi.org/10.1051/matecconf/20168501014

[26] M. Barsoum, Fundamentals of Ceramics, Chap. 10, McGraw-Hill, New York, 1997.

[27] Johari, Izwan, et al. "Effect of the change of firing temperature on microstructure and physical properties of clay bricks from Beruas (Malaysia)." Science of Sintering 42.2 (2010): 245-254 https://doi.org/10.2298/SOS1002245]

Ref.

Ibrahim, Jamal-Eldin F. M. - Shushkov, Dmitry A. - Kurovics, Emese - Tihtih, Mohammed - Kotova, Olga B. - Pala, Péter - Gömze, László A.: Effect of composition and sintering temperature on thermal properties of Zeolite-Alumina Composite Materials Építőanyag - Journal of Silicate Based and Composite Materials, Vol. 72, No. 4 (2020), 131-134. p. https://doi.org/10.14382/epitoanyag-jsbcm.2020.21

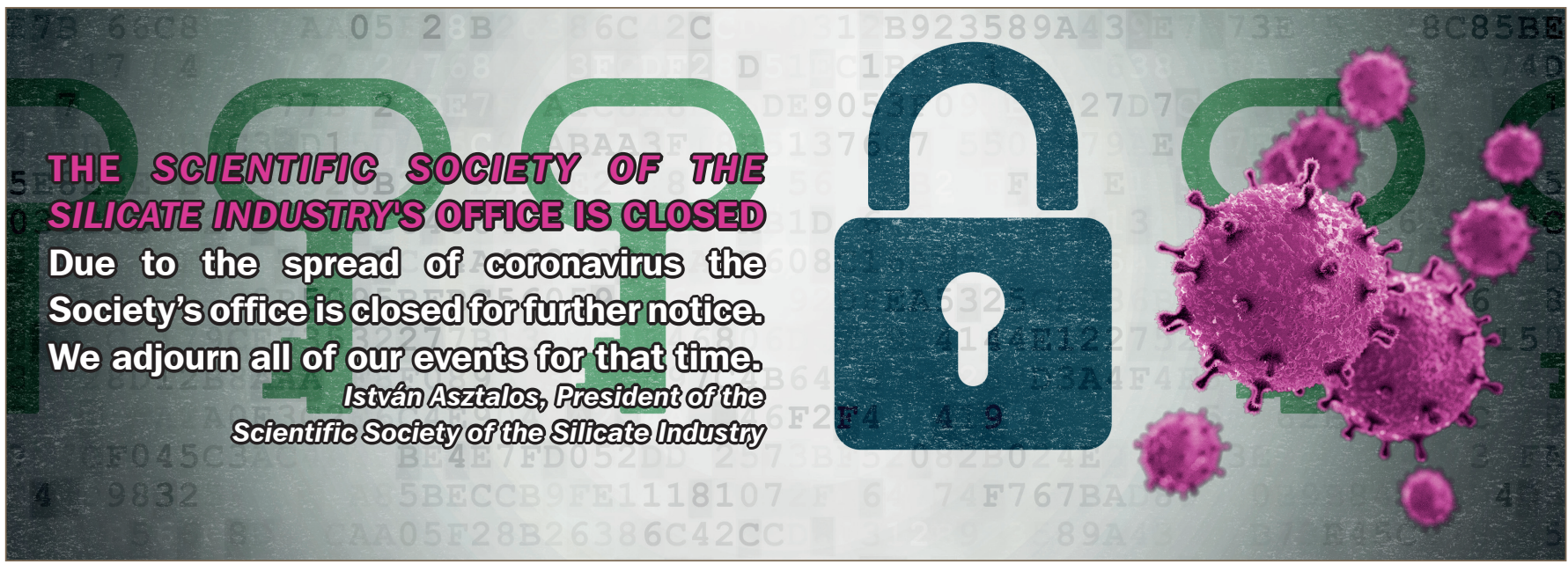

